\title{
The Impact of Global Health Treat COVID-19 on the Implementation of Corporate Innovations in E-commerce Within the Slovak Republic
}

\author{
Ladislav Vagner ${ }^{1, *}$ \\ ${ }^{1}$ University of Zilina, Faculty of Operation and Economics of Transport and Communications, \\ Department of Economics, Univerzitna 1, 01026 Zilina, Slovakia
}

\begin{abstract}
.
Research background: The pandemic of the new coronavirus causing COVID-19 poses a global health threat with a direct impact on individual companies and the country's economy. Estimating the overall effects of COVID-19 is very difficult at the moment, as the situation is evolving every day, and the length of the restrictive measures is not known in advance. As the viruses know no borders, the governments of the affected countries have had to take stringent standards to slow the spread of COVID-19. Among these countries is Slovakia, which has taken many measures that have affected the operation of service companies as well as industry. The disease brought challenges in the field of e-commerce and technology, as isolation and social distancing fundamentally changed the shopping habits of the population.

Purpose of the article: The purpose of this research paper is to highlight how nowadays challenges have affected service businesses and led to the more innovative use of technology and e-commerce. The importance of innovation in adverse conditions caused by business constraints due to Covid-19.

Methods: The analysis in the form of a questionnaire through a questionnaire survey and the subsequent processing of the created database using SPSS using prediction functions were used.

Findings \& Value added: The analyses demonstrated the impact of COVID-19 on e-commerce innovation on a random sample of companies that included companies stimulated to change by this environment to secure their sales, but those that tried to operate without radical change further on the market.
\end{abstract}

Keywords: COVID-19; innovation management; e-commerce; innovation

JEL Classification: $O 31$; $Q 55$; 112

* Corresponding author: ladislav.vagner@,fpedas.uniza.sk 


\section{Introduction}

The impact of the COVID-19 pandemic is gradually being transmitted to all areas of economic life in Slovakia. It affects the functioning of not only those companies that have had to suspend their activities, let alone slow down the spread of the virus among the population. Due to the loss of income caused by quarantine measures, several companies will be at a loss. The share of insolvent companies whose short-term financial assets will not be sufficient to cover losses will increase. We can expect the most significant increase in the most endangered companies dealing with accommodation and catering services, trade and art, entertainment, and recreation [1,2].

However, with a more extended quarantine, several industrial production companies will also come under financial pressure [3]. However, the spread of coronavirus is also a massive shock to the European and world economies. The quarantine, which aims to mitigate the effects of the COVID-19 pandemic on the population's lives and health, will have significant negative consequences for the Slovak economy. The production slowdown and the cessation of many services will be reflected in sales, value-added, and employment decline. When analysing the quarantine's possible effects, it is essential to think about how long revenue-free period companies can cover. The most available, and in the case of many small companies, perhaps the only, source of funds to cover the period of loss of sales are short-term financial assets $[4,5]$.

The demanding period associated with various restrictions, such as the problem of traveling abroad for business or personal mediation of products and services, has become a challenge rather than a limitation for some companies.

A vital aspect of the transformation has been the increased digitization and accelerated implementation of previously anticipated trends, which have been discussed in the information management literature for many years [6]. Human efforts have encouraged us to adapt to the "new norm" of immediate necessity in work, education, healthcare, entertainment and leisure, and online commerce. This new environment has provided the information management research community with unprecedented opportunities to develop research that will significantly impact practice in these and other areas. We are nearly at the forefront of new developments in the digital space. We must strive to develop examples that can help indicate the future direction of the digital global society for the benefit of all $[7,8]$.

The concept of consumer innovation refers to "the interindividual differences that characterize people's responses to new things [9]. The success of e-commerce also depends on consumer culture [10], as culture influences consumer innovation. For businesses it is not easy to create model for sustainable innovation [11] and it is crucial to dispose by intellectual capital [12]. It is important to take account with the risk, which is normally connected with innovation [13] and also right timing [14]. The country is often used as a representative of culture at the group level; however, it is more appropriate to measure culture individually.

Online shopping is an individually targeted event for one person [15]. Similar issues have been addressed by several authors, such as Eysenck et al. [16], who devoted themselves in depth to the Internet. Innovative consumer plays a crucial role in adopting new products. There are at least three approaches to conceptualizing innovation: behavioral, global characteristics, and domain-specific activity [9].

How consumers respond to innovation in e-commerce, particularly whether or not customers adopt new products, depends on their purchasing decision-making process and the different internal and external influences [17, 18]. Measuring cognitive innovation is vital for this process. Consumer perception of information is directly related to cognition 
[19]. Besides, cultural experiences influence cognitive processes [20]; for example, online transactions can cause a high degree of uncertainty [21]. The cultural value of preventing uncertainty is significantly related to innovation [22]. Therefore, consumer innovation plays an essential role in encouraging consumers to shop online [23, 24].

\section{Methodology}

Data analysis using a statistical approach via SPPS was preceded by data collection and creating a relevant database. Data were collected through a questionnaire survey, and a total of 81 companies were contacted. Businesses that fall into small and medium-sized enterprises with a turnover of up to 10 million $€$ were addressed. The data were processed and analysed by the SPSS technique Point-Biserial Correlation with Multiple Dichotomous Variables based on the obtained data.

We also used the analysis method in processing theoretical knowledge related to current issues in e-commerce during the coronavirus pandemic from different countries to identify the impact on innovation in e-commerce. At the same time, these data were synthesized and the results of the analysis to provide a comprehensive conclusion.

\section{Results}

We chose two independent variables to analyse the impact of COVID-19, the dichotomous predictor variables: delivery and e-shop.

Delivery is a variable introduced by companies at the time of the corona crisis to streamline their turnover and business closures.

The second variable is the introduction or eventual adaptation of the e-shop.

The output is an increase/decrease, i.e., an increase or decrease in sales for a given month compared to the same month last year in the given company.

Table 1. Setting Word's margins

\begin{tabular}{|c|c|c|c|c|c|}
\hline \multicolumn{6}{|c|}{ Crosstab } \\
\hline & & & \multicolumn{2}{|c|}{ OUTCOME } & \multirow[b]{2}{*}{ Total } \\
\hline & & & decrease & increase & \\
\hline \multirow[t]{10}{*}{ DELIVERY } & \multirow[t]{5}{*}{ no } & Count & 30 & 5 & 35 \\
\hline & & Expected Count & 19,4 & 15,6 & 35,0 \\
\hline & & \% within DELIVERY & $85,7 \%$ & $14,3 \%$ & $100,0 \%$ \\
\hline & & \% within OUTCOME & $66,7 \%$ & $13,9 \%$ & $43,2 \%$ \\
\hline & & $\%$ of Total & $37,0 \%$ & $6,2 \%$ & $43,2 \%$ \\
\hline & \multirow[t]{5}{*}{ yes } & Count & 15 & 31 & 46 \\
\hline & & Expected Count & 25,6 & 20,4 & 46,0 \\
\hline & & $\%$ within DELIVERY & $32,6 \%$ & $67,4 \%$ & $100,0 \%$ \\
\hline & & \% within OUTCOME & $33,3 \%$ & $86,1 \%$ & $56,8 \%$ \\
\hline & & $\%$ of Total & $18,5 \%$ & $38,3 \%$ & $56,8 \%$ \\
\hline \multirow[t]{5}{*}{ Total } & & Count & 45 & 36 & 81 \\
\hline & & Expected Count & 45,0 & 36,0 & 81,0 \\
\hline & & \% within DELIVERY & $55,6 \%$ & $44,4 \%$ & $100,0 \%$ \\
\hline & & $\%$ within OUTCOME & $100,0 \%$ & $100,0 \%$ & $100,0 \%$ \\
\hline & & $\%$ of Total & $55,6 \%$ & $44,4 \%$ & $100,0 \%$ \\
\hline
\end{tabular}


Due to the nature of the variables, Chi-square tests were first performed (Table 1).

Based on the analysis of the independent variable "delivery," those companies that did not introduce it at the time of the pre-crisis recorded a decrease in sales from 35 companies and 30 companies compared to the previous period, and only five companies increased. Conversely, those enterprises that decided to introduce supplies with increased hygiene measures out of 46 enterprises, 15 enterprises recorded a decrease, and 31 increased.

In summary, it could be stated that those companies that introduced a delivery system recorded an increase in sales compared to the previous period.

E-commerce business depends on the ability to get your products to customers who have ordered them [25]. However, you can do much more than just transport to expand your business. The critical stages of delivery are, firstly, the possibility of delivery obtaining an order, secondly, delivery after purchase - it is time to impress the customer and receive another order, and thirdly, to improve efficiency to overcome internal challenges.

At the time of the corona crisis, the post office limited the delivery of packages. By the fact that several companies were closed, they began to secure transport for their products at their own expense.

Based on the analysis of the independent variable "delivery," those companies that did not introduce it at the time of the pre-crisis recorded a decrease in sales from 35 companies and 30 companies compared to the previous period, and only five companies increased. Conversely, those enterprises that decided to introduce supplies with increased hygiene measures out of 46 enterprises, 15 enterprises recorded a decrease, and 31 an increase. In summary, it could be stated that those companies that introduced a delivery system recorded an increase in sales compared to the previous period.

Table 2. Setting Word's margins

\begin{tabular}{|c|c|c|c|c|c|}
\hline \multicolumn{6}{|c|}{ Crosstab } \\
\hline & & & \multicolumn{2}{|c|}{ OUTCOME } & \multirow[b]{2}{*}{ Total } \\
\hline & & & decrease & increase & \\
\hline \multirow[t]{10}{*}{ e-shop } & \multirow[t]{5}{*}{ no } & Count & 30 & 8 & 38 \\
\hline & & Expected Count & 21,1 & 16,9 & 38,0 \\
\hline & & $\%$ within e-shop & $78,9 \%$ & $21,1 \%$ & $100,0 \%$ \\
\hline & & $\%$ within OUTCOME & $66,7 \%$ & $22,2 \%$ & $46,9 \%$ \\
\hline & & $\%$ of Total & $37,0 \%$ & $9,9 \%$ & $46,9 \%$ \\
\hline & \multirow[t]{5}{*}{ yes } & Count & 15 & 28 & 43 \\
\hline & & Expected Count & 23,9 & 19,1 & 43,0 \\
\hline & & $\%$ within e-shop & $34,9 \%$ & $65,1 \%$ & $100,0 \%$ \\
\hline & & $\%$ within OUTCOME & $33,3 \%$ & $77,8 \%$ & $53,1 \%$ \\
\hline & & $\%$ of Total & $18,5 \%$ & $34,6 \%$ & $53,1 \%$ \\
\hline \multirow[t]{5}{*}{ Total } & & Count & 45 & 36 & 81 \\
\hline & & Expected Count & 45,0 & 36,0 & 81,0 \\
\hline & & $\%$ within e-shop & $55,6 \%$ & $44,4 \%$ & $100,0 \%$ \\
\hline & & $\%$ within OUTCOME & $100,0 \%$ & $100,0 \%$ & $100,0 \%$ \\
\hline & & $\%$ of Total & $55,6 \%$ & $44,4 \%$ & $100,0 \%$ \\
\hline
\end{tabular}

The introduction of an e-shop has a significant impact on e-commerce. This issue was included in the survey, and 38 companies, despite the restrictions related to Covid-19, launched an e-shop, and up to 30 companies recorded lower sales. Forty-three companies decided to set up a website and e-shop, while 28 of them recorded an increase in sales, and the remaining 15 had lower sales.

Under SPSS, the decrease in revenue is encoded as zero and the increase as one. Based on the outputs from the analysis in SPSS, we can state a statistically significant output in Table 3 Variables in the equation. 
Table 3. Variables in the Equation

\begin{tabular}{|l|l|r|r|r|r|r|r|}
\hline \multicolumn{2}{|l|}{} & B & S.E. & Wald & df & \multicolumn{1}{c|}{ Sig. } & Exp(B) \\
\hline Step 0 & Constant &,- 223 &, 224 &, 996 & 1 &, 010 &, 800 \\
\hline
\end{tabular}

Within the Model Summary (Table 4), it is clear that R square is $42.1 \%$ of the depended variables explained using predicted variables.

Table 4. Model Summary

\begin{tabular}{|l|r|r|r|}
\hline Step & -2 Log likelihood & Cox \& Snell R Square & Nagelkerke R Square \\
\hline 1 & $80,716^{\mathrm{a}}$ &, 314 &, 421 \\
\hline
\end{tabular}

a. Estimation terminated at iteration number 5 because parameter estimates changed by less than, 001 .

Based on the results, the predicted variables are statistically significant concerning a level of confidence of less than 0.05 . The prediction of the development of the company's situation depends on the value given in Exp (B). According to Table 5, it is clear that a company that decides to set up an e-shop during a pandemic crisis has up to 8.33 times better chance of increasing sales than those without e-shop. In the case of securing delivery, the increase in revenues has the probability of growth, especially four times greater than for those companies that do not include delivery in their services.

Table 4. Variables in the Equation

\begin{tabular}{|c|c|c|c|c|c|c|c|c|c|}
\hline & \multirow[b]{2}{*}{ B } & \multirow[b]{2}{*}{ S.E. } & \multirow[b]{2}{*}{ Wald } & \multirow[b]{2}{*}{ df } & \multirow[b]{2}{*}{ Sig. } & \multirow[b]{2}{*}{$\operatorname{Exp}(B)$} & \multicolumn{2}{|c|}{$\begin{array}{l}\text { 95\% C.I.for } \\
\text { EXP(B) }\end{array}$} \\
\hline & & & & & & & & Lower & Upper \\
\hline \multirow{3}{*}{$\begin{array}{l}\text { Step } \\
1^{\text {a }}\end{array}$} & DELIVERY(1) & $-2,119$ & ,604 & 12,313 & 1 &, 000 &, 120 &, 037 & ,392 \\
\hline & e-shop(1) & $-1,391$ & ,569 & 5,979 & 1 & ,014 & 249 & ,082 & 759 \\
\hline & Constant & 1,173 & ,386 & 9,251 & 1 & ,002 & 3,233 & & \\
\hline
\end{tabular}

a. Variable(s) entered on step 1: DELIVERY, e-shop.

\section{Conclusion}

Based on the analyses, it is possible to conclude that the disease that affected the company's entire functioning also resulted in forcing companies to make changes in e-commerce. The research document is an initial analysis of the impact of the disease on e-commerce, and it is necessary to address this issue in the longer term with a time interval of 2-3 years. Also, performing the analysis on a larger sample of companies should depend on the business's nature to increase the output's relevance.

Due to distance clearance and closing and isolating businesses, they have begun to innovate their processes within e-commerce. They introduced an e-shop website, streamlined their website, and, if necessary, secured their transport, which ensured increased hygiene criteria required by the Health Authority of the Slovak Republic. We managed to prove that the companies that decided to make these changes achieved a higher or the same amount of sales than in the previous period.

This paper was supported by the VEGA 1/0619/20 Fundamental research of quantitative and qualitative determinants of enterprise innovation potential and innovation performance in relation to increasing its competitiveness. 


\section{References}

1. Whiley, H., Keerthirathne, T.P., Nisar, M.A., White, M.A., Ross, K.E. (2020). Viral Filtration Efficiency of Fabric Masks Compared with Surgical and N95 Masks. Pathogens, 9(9), 762.

2. Klepek, M., Matusinska, K. (2016). Czech Singles in the Market of Services. Acta Universitatis Agriculturae et Silviculturae Mendelianae Brunensis, 64(5), 1731-1738.

3. Simakova, J., Stavarek, D., Prazak, T., Ligocka, M. (2019). Macroeconomic Factors and Stock Prices in the Food and Drink Industry. British Food Journal, 121(7), 16271641.

4. Valaskova, K., Durana, P., Adamko, P., Jaros, J. (2020). Financial Compass for Slovak Enterprises: Modeling Economic Stability of Agricultural Entities. Journal of Risk and Financial Management, 13(5), 92.

5. Hussain, H.I., Kot, S., Kamarudin, F., Wong, C.M. (2020). The Nexus of Competition Freedom and the Efficiency of Microfinance Institutions. Journal of Competitiveness, 12(2), 67-89.

6. Prazak, T., Stavarek, D. (2018). The Importance of Financial Ratios in Predicting Stock Price Trends: Evidence from Central European Countries. International Journal of Trade and Global Markets, 11(4), 293-305.

7. Barnes, S. J. (2020). Information management research and practice in the postCOVID-19 world. International Journal of Information Management, 55, Art. No. 102175.

8. Sanusi, K.A., Meyer, D., Ślusarczyk, B. (2017). The relationship between changes in inflation and financial development. Polish Journal of Management Studies, 16(2). 253-265.

9. Goldsmith, R.E., Foxall, G.R. (2003). The measurement of innovativeness. The international handbook on innovation, 321-330.

10. Sohaib, O., Kang, K. (2015a). Individual level culture influence on online consumer iTrust aspects towards purchase intention across cultures: A SOR model. International Journal of Electronic Business, 12(2), 142-161.

11. Ludbrook, F., Michalikova, K.F., Musova, Z., Suler, P. (2019). Business models for sustainable innovation in industry 4.0: Smart manufacturing processes, digitalization of production systems, and data-driven decision making. Journal of Self-Governance and Management Economics, 7(3), 21-26.

12. Zygmunt, A. (2019). External linkages and intellectual assets as indicators of firms' innovation activities: results from the Czech Republic and Poland. Oeconomia Copernicana, 10(2), 291-308.

13. Janoskova, K., Kral, P. (2015). Optimal timing of innovation as a precondition of successful innovation on the global market. In T. Kliestik (Ed.). Globalization and Its Socio-Economic Consequences (pp. 254-259). University of Zilina: Slovakia.

14. Janoskova, K., Kral, P. (2016). Acceptance of Risk of Innovations as an Important Assumption of Innovative Organization. In H. Zhang (Ed.) International Conference on Information, Communication and Social Sciences (ISSGBM-ICS 2016) (pp. 3-7). Singapore: Singapore.

15. Sohaib, O., Kang, K. (2015b). AIS Electronic Library (AISeL).

16. Eysenck, G., Kovalova, E., Machova, V., Konecny, V. (2019). Big data analytics processes in industrial internet of things systems: Sensing and computing technologies, 
machine learning techniques, and autonomous decision-making algorithms. Journal of Self-Governance and Management Economics, 7(4), 28-34.

17. Van Thanh, D.O. (2000). Security issues in mobile ecommerce. In Proceedings 11th International Workshop on Database and Expert Systems Applications, 1875, 412-425.

18. Wei, K.K., Sia, C.L., Teo, H.H., Liu, C. (2008). The impact of institutional forces on $\mathrm{B} 2 \mathrm{~B}$ ecommerce diffusion. Information management in the modern organizations: trends \& solutions, 1-2, 289-389.

19. Ha, H.Y., John, J., John, J.D., Chung, Y.K. (2016). Temporal effects of information from social networks on online behavior. Internet Research, 26(1), 213-235.

20. Faiola, A., Matei, S. (2007). Cultural Cognitive Style and the Web: Toward a Theory and Practice of Web Design for International Users. In Linguistic and Cultural Online Communication Issues in the Global Age (pp. 143-159). IGI Global.

21. Sabiote, C. M., Frías, D. M., Castañeda, J. A. (2012). E-service Quality as Antecedent to E-satisfaction. Online Information Review, 36(2), 157-174.

22. Dobre, C., Dragomir, A., Preda, G. (2009). Consumer Innovativeness: A Marketing Approach. Management \& Marketing, 4(2), 19-34.

23. Sohaib, O., Kang, K., Miliszewska, I. (2019). Uncertainty avoidance and consumer cognitive innovativeness in e-commerce. Journal of Global Information Management (JGIM), 27(2), 59-77.

24. Bauerova, R., Klepek, M. (2018). Technology acceptance as a determinant of online grocery shopping adoption. Acta Universitatis Agriculturae et Silviculturae Mendelianae Brunensis, 66(3), 737-746.

25. Xiao, L., Zhang, Y. (2020). An analysis on the policy evolution of cross-border ecommerce industry in China from the perspective of sustainability. Electronic Commerce Research, 1-25. 